\title{
Mimarlık Tarihi ve Mimari Koruma Ara Kesitinde Bir İnceleme: Üsküdar Şemsi Ahmed Paşa Külliyesi
}

\author{
A Study on the Intersection of Architectural History and Architectural Conservation: \\ Uskudar Şemsi Ahmed Paşa Complex
}

\author{
Safa Meral ${ }^{*} \oplus$, Emre Kishalı* $^{\text {** }}$
}

Öz

Şemsi Ahmed Paşa Külliyesi, 16. yüzyılda isminden de anlaşılacağı üzere uzun yıllar boyunca çeşitli devlet kademelerinde görevlerde bulunmuş Şemsi Ahmed Paşa tarafından Mimar Sinan’a yaptırılmıştır. Bu yapı, barındırdığı nitelikler açısından Osmanlı klasik dönem mimarisi içerisinde, üzerinde dikkatle durulması gereken önemli yapılardan biridir. Yapıyı diğer Sinan yapılarından ayrıcalıklı kılan, işlevlerin plan yerleşiminde farklı kurgulanması ve ölçek olarak en küçük külliye yapısı olarak inşa edilmesidir. Külliyenin küçük olması veya yerleşimin asimetrik olması onu değersizleştirmemiş bilakis parçaların birbirine eklemlenerek bir bütüne ulaşması ve bağlamı içerisinde dengeli ve uyumlu bir biçimde kurgulanması onu estetik kılmış ve Üsküdar'ın siluetinde önemli bir yer edinmesine sebep olmuştur. Bu makalede yapının bağlamı ve bunun zaman içinde değişimi, özel olarak yapının mimari özellikleri, geçirdiği onarımlar üzerinde durulmuştur. En son olarak da yapının son restorasyon çalışmasından sonra güncel hasar tespit analizi yapılmıştır. Kullanımdan kaynaklı, nem kaynaklı ve yapısal bozulmalar tespit edilmiştir. Ayrıca, termal kamera destekli fotoğraflar üzerinden ilgili bozulmaların sebepleri irdelenmeye çalışılmıştır.

Anahtar Kelimeler

Şemsi Ahmed Paşa Külliyesi, Osmanlı Klasik Dönem Mimarisi, Mimar Sinan, Üsküdar, Restorasyon

\begin{abstract}
Şemsi Ahmed Pasha Complex was built in the 16th century by Şemsi Ahmed Pasha, who had served at various state levels for many years. This structure is one of the important structures that should be considered carefully in Ottoman Classical Period Architecture in terms of the qualities it carries. What makes the complex unique compared to other Sinan structures is that the functions are constructed in a different layout plan and also this complex of buildings is the smallest of all such Ottoman constructions. The fact that it is small or that the complex is asymmetric does not depreciate its value, but rather the parts that make up the whole by being shaped together in a balanced and harmonious way make it aesthetic and cause it to have an important place in the silhouette of Uskudar. In this article, the context of the structure and its change over time, the architectural features of the building and the repairs it has undertaken are emphasized. Finally, after the last restoration work, the current damage assessment analysis was carried out. Damage caused by use, moisture-induced deterioration and structural deterioration were determined. In addition, this study attempts to examine the reasons for the damage to the building by use of thermal camera assisted photographs.
\end{abstract}

\section{Keywords}

Şemsi Ahmed Paşa Complex, Ottoman Classical Period Architecture, Mimar Sinan, Uskudar, Restoration

* Sorumlu Yazar: Safa Meral (Mimar, YL Öğrencisi), Kocaeli Üniversitesi, Fen Bilimleri Enstitüsü, Mimarlık Anabilim Dalı, Kocaeli, Türkiye. E-posta: sfmeral@gmail.com ORCID: 0000-0002-9344-2224

** Emre Kishalı (Dr. Öğr. Üyesi), Kocaeli Üniversitesi, Mimarlık ve Tasarım Fakültesi, Mimarlık Bölümü, Kocaeli, Türkiye. E-posta: emre.kishali@kocaeli.edu.tr ORCID: 0000-0002-1740-5042

Atıf: Meral, Safa ve Kishali, Emre. “Mimarlık Tarihi ve Mimari Koruma Ara Kesitinde Bir İnceleme: Üsküdar Şemsi Ahmed Paşa Külliyesi." Art-Sanat, 13 (2020): 313-334. https://doi.org/10.26650/artsanat.2020.13.0013 


\section{Extended Summary}

Şemsi Ahmed Paşa Complex was designed by Mimar Sinan who used a very different approach in its construction. Although at first glance it may seem that the building has an irregular layout, the fact that the various parts of the building are connected to each other in order to form a whole creates a sense of harmony. It was constructed in a balanced and harmonious manner within its own context; therefore, it has gained an important place in the silhouette of Üsküdar with its own unique aesthetic value. Apart from the mosque, the complex includes a madrasa and a tomb adjacent to the mosque. In this structure, Sinan did not follow the classical geometric boundaries and he differentiated the axis of the L-shaped madrasah from the mosque in the qibla axis and placed it perpendicular to the Bosphorus.

When the construction technique and material are examined, it is seen that the mosque and tomb are constructed with küfeki stone and the roof elements are covered with lead. Most of the masonry walls of the madrasah were built with one row of stones and three rows of bricks. It is obvious that Sinan requested to display the high quality and grade level of the two structures by differentiating the construction techniques. However, the facade of the madrasah facing the Bosphorus was similar to that of the mosque which was built by küfeki stone. It is also understood that uniformity in terms of material is desired on the facade of the complex seen from the sea.

This remarkable building has survived various repairs throughout history. It is on record that the complex was repaired in 1871,1885, 1892 and 1896. The complex was not repaired between 1898-1938. In 1940, the ruined complex was finally restored. Lastly, the mosque and tomb in the complex underwent a restoration work in 2008-2010. The restoration of the madrasah structure started in 2012. Of all the repairs, the restoration in 1940 played a vital role in the conservation and the survival of the structure.

As the last restoration work was carried out recently, our examination of the building did not find any structural damage. However tructural cracks were noticed in the garden walls. It is claimed that the piling operations into the sea within the scope of "Üsküdar Square Arrangement Project" caused the cracks in the garden walls. In addition, closer investigation shows that there are cracks on the plaster and damage caused by moisture in the mosque and madrasa.

Using infrared thermography (IRT) study, cooler areas on the northwest inner surface of the mosque were identified. This could be caused by humidity and the penetration of rain into the interior part from the area where the minaret and the half-domed element are connected. In addition, when the inner surface of the northeastern façade of the mosque was examined by (IRT), colder surfaces were also detected in the connection of the vault of the tomb with the load-bearing walls. When the inner surface of the tomb was examined, interventions with cement-based plaster were observed. Plaster spills and discoloration were also noticed on the northern inner surface of the 
madrasah. It is thought that this situation was caused by water coming from the window due to poor workmanship from the last restoration. The madrasah, which is currently a library, has been extensively used. This intense use affects the micro-climatic condition of the madrasah and as a result, the plaster in the classroom has suffered some damage

Over the last 150 years, the urban context of the building complex has been constantly changing. After the destruction of the Serefabad Pavilion to the west of the complex in 1869 , the area became a square, after which the square gradually turned into a commercial and entertainment place in the first half of the 20th century. Later, with the opening of the coastal road in the 1980s, the old square had to be demolished. After the collapse of the Tekel buildings and Balaban Pier, located to the east of the Şemsi Ahmet Paşa complex, the boundaries of Üsküdar Square expanded into the complex. Finally, by means of recent land reclamation, the complex is now surrounded by commercial spaces in a big area. Thus we can see how the surroundings of the complex has been greatly affected by urban changes in the area. In this respect, it can be seen that the primary threat in passing the complex on to future generations is not caused by structural problems but rather is due to improper urbanization policies.

In summary, after the most recent repairs, damage to the complex was mainly caused by moisture. In historic buildings, which have recently been restored, deterioration problems are usually caused by moisture. The necessity of restoration practices in accordance with the principles of sustainable protection have come to light again through this study. In addition, the concept of conservation needs to be developed by keeping urban memory alive without ignoring the historical context that exists and coexists with it, and not exclusively considering the historical structure. These requirements have become evident once again particularly in regard to the Şemsi Ahmed Paşa Complex. 


\section{Giriş}

Osmanlı klasik dönem mimarisi, devletin diğer alanlarında atılım içerisinde olduğu bir döneme, 16. yüzyıla rast gelmektedir. Güçlü devletlerin tarihte iz birakabilmeleri için tek başına askeri veya ekonomik olarak ön planda olmaları yetmemektedir, aynı zamanda sosyal ve kültürel anlamda da yeni öneriler sürmeleri gerekmektedir. Bu minvalde klasik dönem mimarisi, bu izin yoğun hissedildiği bir dönemdir ve hiç şüphesiz bu mimarinin oluşmasında en büyük katkı sahiplerinden biri de Mimar Sinan'dır. Sinan, yaptığı çalışmalarla yeni bir üslubun oluşmasına vesile olmuştur. Selimiye gibi heybetli ve büyük ölçekli bir külliyenin ardından bu derece mütevazı bir külliyeyi vücuda getirebilmek Sinan'ın sürekli bir arayış içerisinde olduğunun ve bu anlamda herhangi bir zihnî tabusunun olmadığının göstergesidir. Aptullah Kuran’ın da ifade ettiği üzere Üsküdar Şemsi Ahmed Paşa Külliyesi Sinan'ın en kayda değer eserlerinden biridir. ${ }^{1}$ Çünkü Sinan, üzerine kurulduğu bu küçük ve zor arazide cami, türbe ve medreseden oluşan yapı grubunu alışılagelmiş olandan farklılaştırarak yeni bir yerleşim düzeni içerisinde çözmüştür.

Bu kayda değer eser, tarih boyunca çeşitli onarımlar görerek günümüze kadar ulaşmıştır. 1871, 1885, 1892, 1896 yıllarında tamir edildiği tespit edilen külliyenin, 1898 yılından 1938 yılına kadar kendi haline bırakıldı ğ ${ }^{2}$, oldukça harap durumda olan yapının 1940 yılındaysa nihayet onarımının gerçekleştiği görülmektedir. Külliye içerisinde yer alan cami ve türbe en son 2008-2010 y1llarında bir restorasyon çalışması geçirmiştir. Medrese yapısının restorasyon çalışmalarıysa 2012 yılında başlamıştır.

Çalışmanın amacı mimarlık tarihi ve mimari koruma disiplinleri ara kesitinde günümüze kadar ulaşmış bu külliye yapılarının güncel sorunlarını kent ve yapı ölçeğinde tartışmaktır. 21. yüzyıl güncel koşulları göz önüne alındığında yapının maruz kaldığ1 onarımlar üzerinden mevcut sorunlar tartışılmıştır. Bu çalışmada, literatür taraması yapıldıktan sonra yapılar dışarıdan gözlem yoluyla ve kızılötesi kamera çekimleriyle yerinde incelenmiştir. Mevcut bozulmalar yakın zamanda onarım görmüş olan yapılar özelinde sunulmuştur.

\section{Külliyenin Konumu ve Tarihsel Bağlam}

Şemsi Ahmed Paşa Külliyesi, Üsküdar'ın merkezini tanımlayan Mihrimah Sultan Külliyesi, Yeni Valide Külliyesi gibi yapılarla çevrili Üsküdar meydanına ve yoğun kullanıma sahiplik eden Marmaray-Metro istasyonuna yakın bir konumda yer almaktadır. Külliyenin parçası olan cami yapısıysa Salacak istikametine doğru Rum Mehmed Paşa Camii'nin kuzeyinde, kıyı üzerinde yalı camii denilebilecek bir pozisyondadir (G. 1).

1 Aptullah Kuran, Mimar Sinan (İstanbul: Hürriyet Vakfı, 1986), 193.

2 Oya Şenyurt, "Şemsi Ahmed Paşa'nın Üsküdar'daki Yapıları Üzerine Bir Değerlendirme,” Kocaeli Üniversitesi Sosyal Bilimler Dergisi 35 (2018): 184. 


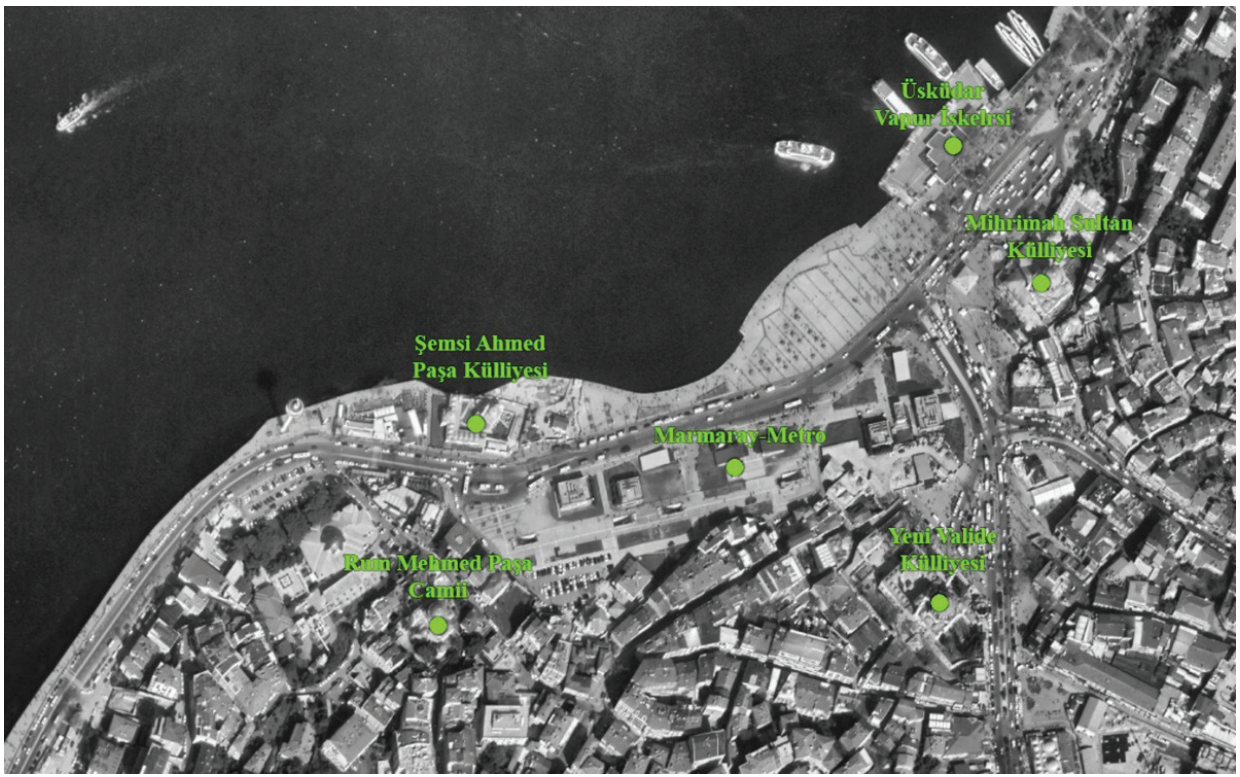

G. 1. Şemsi Ahmed Paşa Külliyesi'nin konumu (Google Earth, 2019)

Caminin banisi olan Şemsi Ahmed Paşa, Candaroğulları Beyliği’nin İsfendiyar ailesine mensup Kastamonu Beyi Kızıl Ahmed'in torunu ve Mirza Mehmed Paşa’nın oğludur. Babası Mirza Mehmed Paşa, Bolu ve Erzincan sancak beyi görevlerinde bulunmuştur. ${ }^{3}$ Annesiyse Osmanoğulları hanedanından II. Bayezid'in evladından Şehzade Abdullah'ın kızıdır. Şemsi Ahmed Paşa, Yavuz Sultan Selim’in hizmetinde bulunmuş, Enderun'dan Müteferrika'ya çıkmış ve Sipahioğlanları Ağası olmuştur. ${ }^{4}$ Paşa, 1555'te Şam beylerbeyliği, Nisan 1560'tan itibaren ise sirasıyla Rum (Sivas), Anadolu ve Rumeli beylerbeyliklerine atanmıştır. Tarihçi Mustafa Âli, Şemsi Ahmed Paşa'yı Sultan Süleyman'ın “av musahibi”, II. Selim’in "1yş ü işret arkadaşı”, III. Murad'ın "devlet işlerinde yoldaşı" olarak betimler. ${ }^{5}$

Şemsi Ahmed Paşa, ikametgâh olarak Üsküdar'da oturuyordu ve kaynaklarda II. Selim'in sık sık paşayı burada ziyaret ettiği yazmaktadır. ${ }^{6}$ Külliyenin yapılışından önce buraya çok yakın bir konumda, Pervititch haritasında Şemsi Paşa Meydanı olarak belirtilen yerde, bir kasır yaptırmış ve bunu Sultan III. Murad'a hediye etmiştir. ${ }^{7}$ Ayrıca, sadece III. Murad değil, aynı zamanda çeşitli tamirlerle III. Ahmed ve II. Mahmud da bu yapıyı ikametgâh olarak kullanmıştır. ${ }^{8}$ III. Ahmed döneminde (1703-1730) esaslı bir

3 Abdülhamit Tüfekçioğlu, "Üsküdar ve Şam Arasındaki Köprü: Şemsi Ahmed Paşa ve Mimari Eserleri,” 1. Üsküdar Sempozyumu (İstanbul: Üsküdar Belediyesi, 2003), 2: 9-25.

4 Tüfekçioğlu, "Üsküdar ve Şam Arasındaki Köprü: Şemsi Ahmed Paşa ve Mimari Eserleri," 9-25.

5 Gülru Necipoğlu, Sinan Çăgl: Osmanlı Imparatorluğu'nda Mimari Kültür (İstanbul: İstanbul Bilgi Üniversitesi Yayınları, 2013), 658.

6 G. Necipoğlu, Sinan Çă̆l: Osmanlı İmparatorluğu'nda Mimari Kültür, 660.

7 Mehmet Nermi Haskan, Yüzyıllar Boyunca Üsküdar (İstanbul: Üsküdar Belediyesi, 2001), 1: 350.

8 Şenyurt, “Şemsi Ahmed Paşa’nın Üsküdar'daki Yapıları Üzerine Bir Değerlendirme,” 180. 
tamirin ardından "Şerefâbâd" adı ile kullanılmıştır. 1816 yılında II. Mahmud döneminde Ampir üslubunda tekrar inşa edilen saray, "Şemsi Paşa Sarayı" adıyla anılmaya devam etmiştir. Abdülmecid'in saltanatının son yıllarında yapı harap olmuştur.9

Şemsi Ahmed Paşa, Sultan III. Murad'a hediye ettiği bu kasırla birlikte 1580 y1lında külliyenin yapım faaliyetlerini Mimar Sinan'a başlatmıştır. Lakin külliyenin bitimini görmeye ömrü vefa etmemiştir. Ayrıca kaynaklarda cami, türbe ve medrese haricinde Mimar Sinan'ın otobiyografilerinde ismi geçmeyen bir tekke ${ }^{10}$ yapısından da söz edilmektedir.

\section{Mimari Özellikleri}

Külliye, Mimar Sinan'ın farklı bir tasarım anlayışına göre şekillenmiştir. İlk bakışta plan düzleminde düzensiz gibi gözükse de parçaların birbirine eklemlenerek bir bütüne ulaşması ve bağlamı içerisinde dengeli ve uyumlu bir biçimde kurgulanması onu daha estetik kılmış ve Üsküdar'ın siluetinde önemli bir yer edinmesini sağlamıştır. Diğer yandan bu yapı, Sinan'ın inşa ettiği en küçük külliyedir. Cami 8 x8 metre ${ }^{11}$ ebatlarında kare planlı olup ancak çok küçük bir cemaati bünyesinde toplayabilir. Caminin dışında, külliyede, medrese ve camiye bitişik konumda bir türbe mevcuttur. Sinan, bu yapısında klasik geometrik sınırların dışında kalmış, L biçimindeki medresenin aksını kıble aksındaki camiden farklılaştırarak boğaza dik doğrultuda yerleştirmiştir. Böylece cami ve medresenin ilişkisi plan düzleminde alışılagelmişin dışında bir görünüme bürünmüştür. ${ }^{12}$ (G. 2)

Külliyenin ana kapısı doğudadır ve ön avluda caminin kıble aksı istikametinde bir hazire mevcuttur. Caminin güney ucuyla medresenin birleştiği aralıktan asıl avluya geçilmektedir. Avlu serbest biçimli ve asimetriktir, denize doğru açılmaktadır (G. 2). Avlu duvarının şeffaflığı denize yönelim isteğini göstermektedir. Bu durumu Aptullah Kuran şöyle nitelemektedir: "Avlu ile deniz arasındaki görsel ilişki doğrudan değil fakat duvara açılan pencereler yoluyla sağlanır. Böylece avluyu kuşatan deniz duvarı her karesinden Boğaz manzaralarının seyredildiği bir resim galerisine dönüşür."13 Turgut Cansever'in ifadesiyle de "Boğaziçi'ni bütün derinliği ile kucaklayan, onunla bütünleşen bir çözümdür.”'14

9 Şenyurt, “Şemsi Ahmed Paşa'nın Üsküdar'daki Yapıları Üzerine Bir Değerlendirme," 180.

10 Necipoğlu, Sinan Çağı: Osmanlı İmparatorluğu'nda Mimari Kültür, 662.

11 Erdem Yücel, "Şemsi Paşa Külliyesi," Arkitekt 336 (1969): 158.

12 Turgut Cansever, Sinan'ın iki kollu medreseden çıanların camiye yönelmelerini sağlamak, camiyi bu iki kolun çevrelediği alanın ortasında yüceltme arzusunun plan oluşumuna sebep olabileceğini düşünmektedir. Benzer bir yaklaşımın Selimiye'de de olduğunu ifade etmektedir. Turgut Cansever, Mimar Sinan (İstanbul: Albaraka Türk Yayınları, 2005), 389.

13 Kuran, Mimar Sinan, 193.

14 Cansever, Mimar Sinan, 394. 


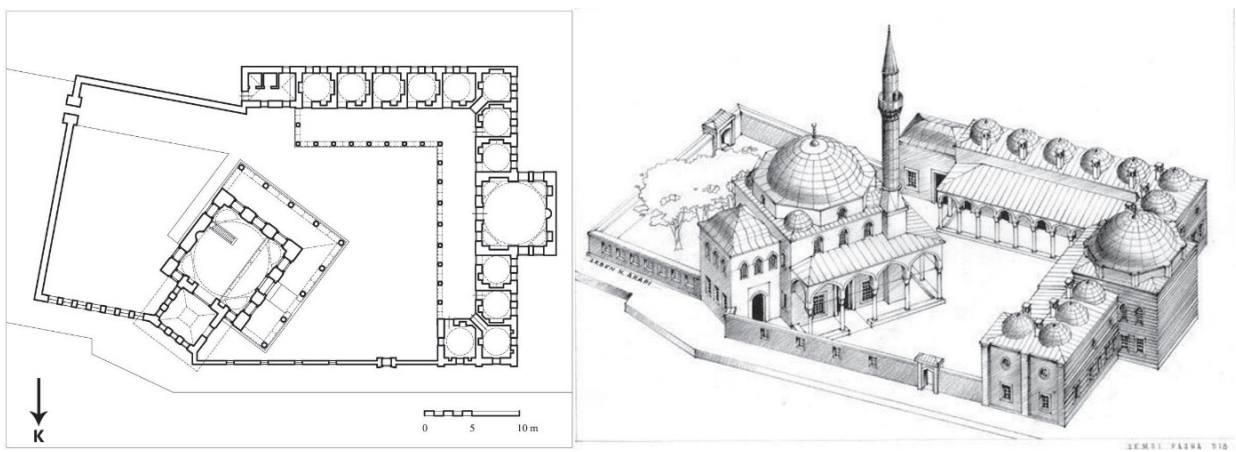

G. 2. Külliyenin plan (sol) ve perspektif görünüşü (sağ) (Necipoğlu, Sinan Çăğ: Osmanlı Imparatorluğu'nda Mimari Kültür, 659)

Giriş kapısı Hereke taş1 ve beyaz mermerle örülmüştür. ${ }^{15}$ Son cemaat yerinde camiyi avluya bakan iki yönde saran baklava dilimli başlıkları olan 8 sütunun taşıdığı, diğer Sinan camilerinde rastlanmayan ${ }^{16}$ kubbesiz eğik çatılı revak kullanılmıştır. Kuzey cephesinde camiden çıkıntı yaparak yüzünü denize dönmüş bir türbe konumlandırılmıştır. Türbe, caminin bir parçası görünümündedir. Cami ve türbe iç mekânda parmaklıkla ayrılmıştır. İstanbul Âbideleri başlıklı kitapta iki yapıyı ayıran parmaklı̆ğın hendesî şekillerle süslenmiş olduğu ifade edilmektedir. ${ }^{17}$ Lakin günümüzde yer alan parmaklığın bu ifadeye uymadığ 1 ve zaman içerisinde değiştiği görülmektedir (G. 3). İnciciyan, cami kubbesinin tepesine alem olarak hilal yerine, banisinin adına izafeten güneş (şems) şekli konulduğunu söylemektedir. ${ }^{18}$ Lakin günümüzde bu alem yoktur. 12 talebe odasından oluşan medresenin boğaza dik gelen kolunun tam ortasında dershane bulunmaktadır. Medreseyi L hareketi boyunca 18 mermer sütunun taşıdığ kubbesiz eğik çatılı bir revak sarmıştır. "Dershane kapısının kemerinde İstanbul'da pek az yapılarda bulunan kırmızı Burgaz taşı kullanılmıştır.”19

15 “Şemsi Paşa Camii,” İstanbul Âbideleri (Yedigün Neşriyat), 116.

16 Kuran, Mimar Sinan, 195.

17 “Şemsi Paşa Camii," 116.

18 P. Ğugios İnciciyan, XVIII. Asırda İstanbul, çev. Hrand D. Andreasyan (İstanbul: İstanbul Fetih Cemiyeti İstanbul Enstitüsü, 1976), 134.

19 “Şemsi Paşa Camii," 116. 


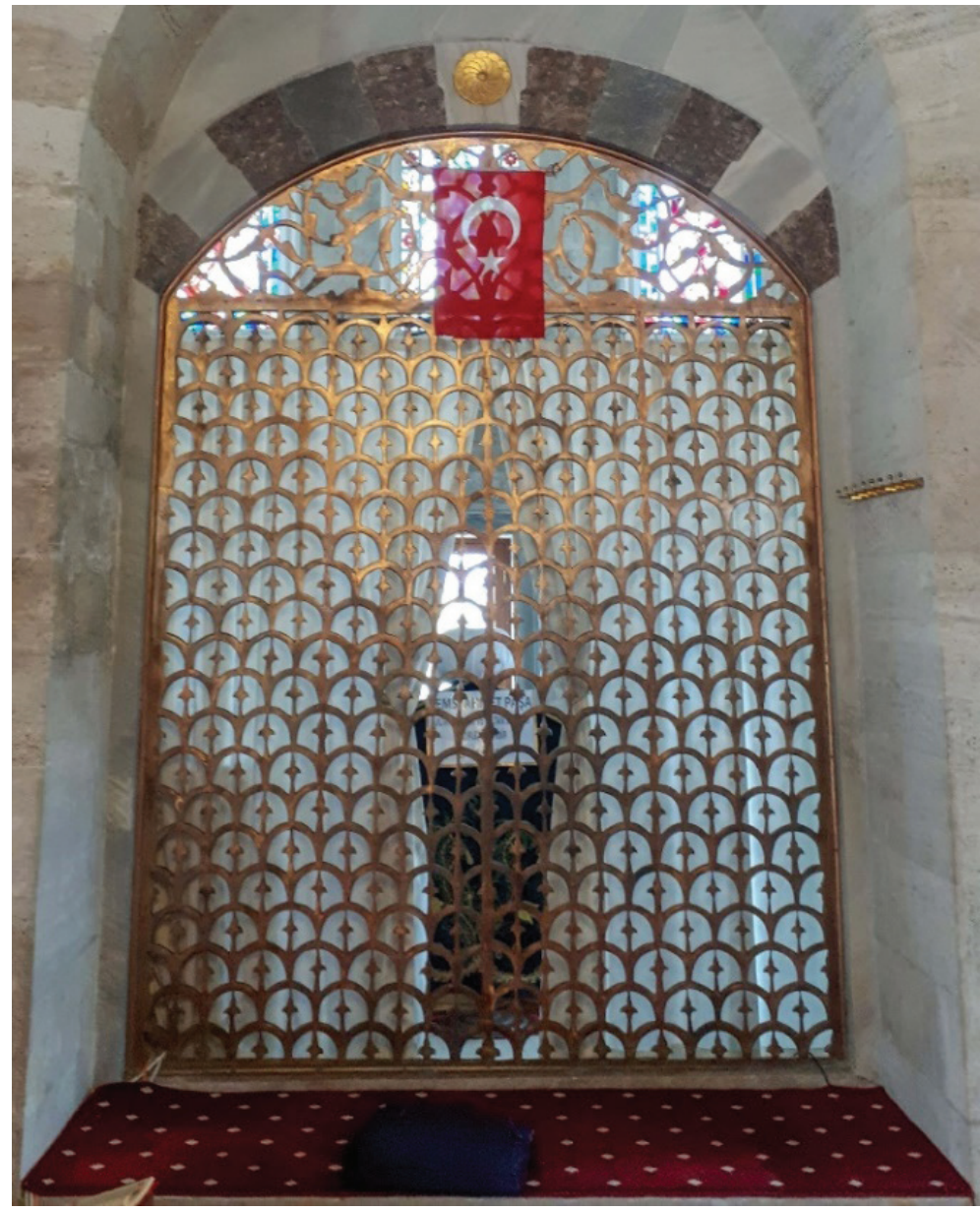

G. 3. Cami ile türbeyi ayıran parmaklıklar (Safa Meral, 2019)

Yapım tekniği ve malzeme açısından incelendiğinde cami ve türbenin düzgün küfeki taşıyla, örtü elemanlarınınsa kurşunla kaplandığı görülmektedir. ${ }^{20}$ Caminin girişinde yapılan çalışmalarda, beden duvarının $110 \mathrm{~cm}$ olduğu ölçülmüştür. Medresenin ise almaşık yapım tekniğiyle inşa edildiği görülmektedir. Genel olarak bir sıra taş, üç sıra tuğlayla örülmüştür. Duvar kalınlığ1 $80 \mathrm{~cm}$ ve kullanılan tuğlaların ölçüsü 30x4 cm olarak belirlenmiştir. Sinan'ın cami ve medrese arasındaki yapım tekniğini farklılaştırmasıyla bu iki yapı arasındaki mahiyet ve mertebe farkını belirlemek istediği anlaşılmaktadır. ${ }^{21}$ Fakat medresenin boğaza bakan cephesi cami ile benzer teknikte düzgün küfeki taşıyla vücuda getirilmiştir. Buradan da külliyenin denize bakan yüzünde malzeme açısından bir yeknesaklığın istendiği de anlaşılmaktadır. 

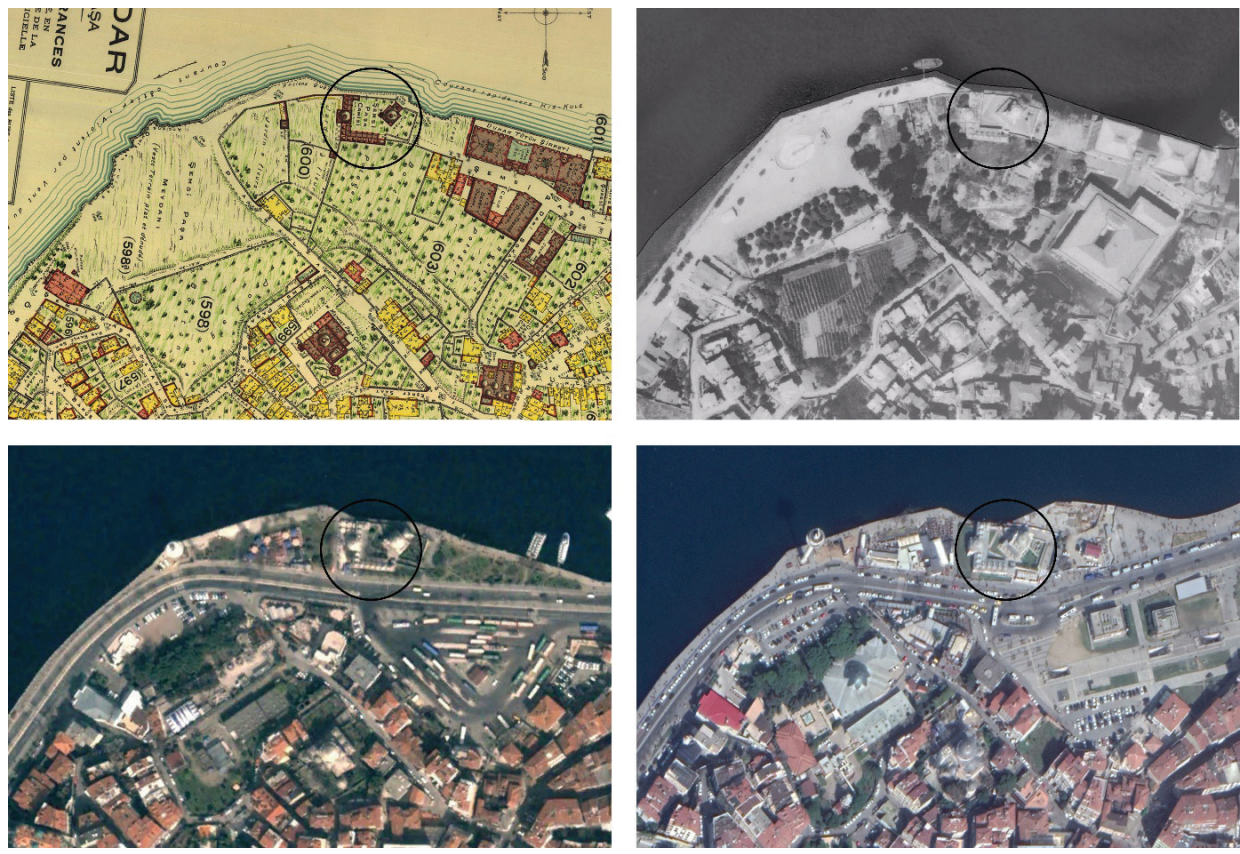

G. 4. Y1llara göre Şemsi Ahmed Paşa Külliyesi'nin şehir bağlamında değişimi,

1. 1930 (Pervititch Haritas1), 2. 1966 (İstanbul Şehir Haritas1), 3. 2002 (Google Earth), 4. 2019 (Google Earth)

\section{Kentsel Bağlamda Tarihsel Süreç İçerisinde Geçirdiği Değişim}

Zamanında Şemsi Ahmed Paşa Külliyesi’nin batısında yer alan Şerefâbâd Kasrı (G. 5), Ahmet Lûtfi Efendi’ye göre 1869 yılında yıkılıp arsası Millet Bahçesi olmak üzere terk edilmiştir. ${ }^{22} 1910$ 'lı yıllardan itibaren yazlık kahvehane, panayır alanı gibi işlevler görmeye başlayan bu boş alanda 1938 yılında deniz kıyısına yakın bir konumda havuz inşa edilmiştir. Bu havuzla birlikte meydanda çeşitli su ve 1şık gösterileri düzenlenmiştir.

Meydanın Salacak istikameti tarafında günümüze ulaşmayan bir başka yapı da Adliye Camii'dir. Bugünkü Atatürk heykelinin biraz gerisinde, orduevinin ise solunda yer alan Adliye Camii (G. 5), Sultan III. Mustafa döneminde yaptırılmış ve 1815 yılında Sultan II. Mahmud tarafından yeni baştan inşa edilmiştir. Tam olarak ne zaman yıkıldı̆̆ 1 bilinmeyen caminin, 1894 yılındaki depremde hasar görmüş olup bir müddet sonra yıkıldığ 1 tahmin edilmektedir. ${ }^{23}$ Lakin Pervititch haritalarında bir dönem Nizam-1 Cedid karakolu olarak kullanılan Anadolu Spor Kulubü’nün (Orduevi) yanında harap halde bir minare gösterilmektedir. Şemsi Ahmed Paşa Külliyesi’nin harap hâldeki vaziyeti Adliye Camii ile aynı döneme denk gelmektedir. 1938 yılındaki 
meydan çevre düzenlemesinin ${ }^{24}$ ardından hakkında onarım kararının alınması külliyenin günümüze ulaşması açısından kritik noktayı oluşturmaktadır.

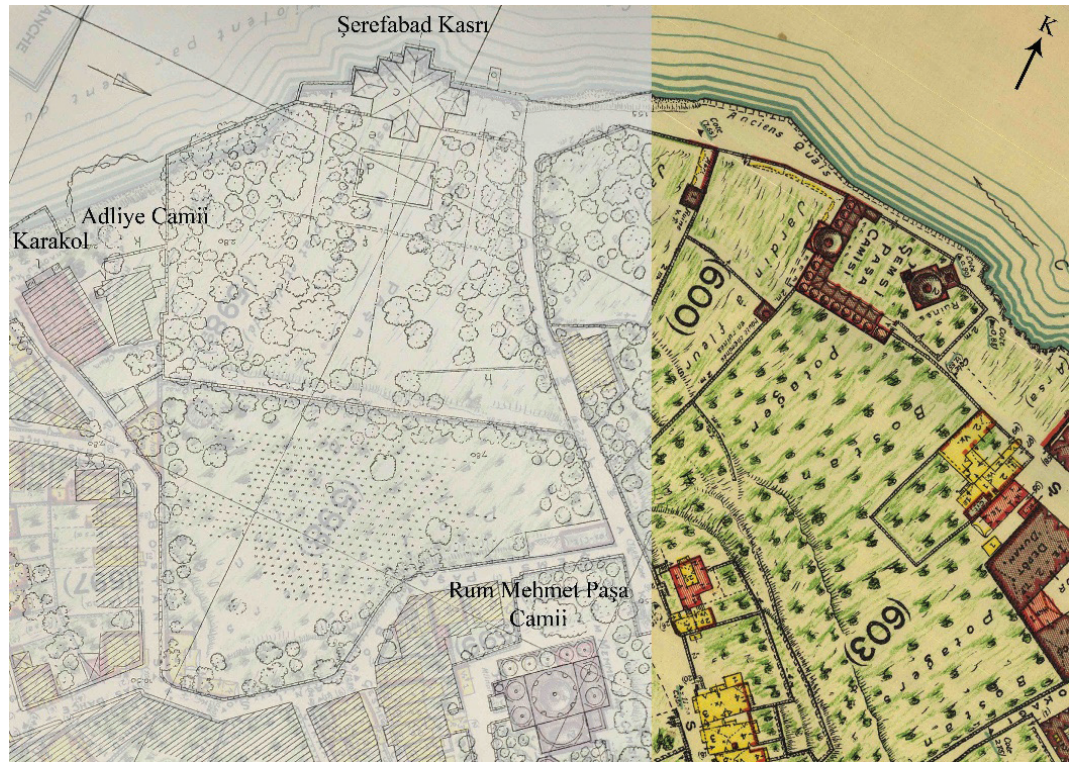

G. 5. Pervititch Haritası ile Sedad Hakkı Eldem'in Şerefâbâd Kasrı Restitüsyon Projesi çakışması

(S. Hakkı Eldem, Köşkler ve kasırlar = A Survey of Turkish Kiosks and Pavilions (İstanbul:

Devlet Güzel Sanatlar Akademisi, 1974), 2: 380)

1930 yılına ait Pervititch haritasında Şemsi Ahmed Paşa Külliyesi'nin batısında çiçek bahçesi, güneyinde ise sebze bahçesinin olduğu görülmektedir (G. 5). Ayrıca yine batısında harabe hâldeki bir bacanın yer aldığı gösterilmiştir. Planlarla örtüşen aşağıdaki (G. 6) fotoğrafta da bu durum görülmektedir.

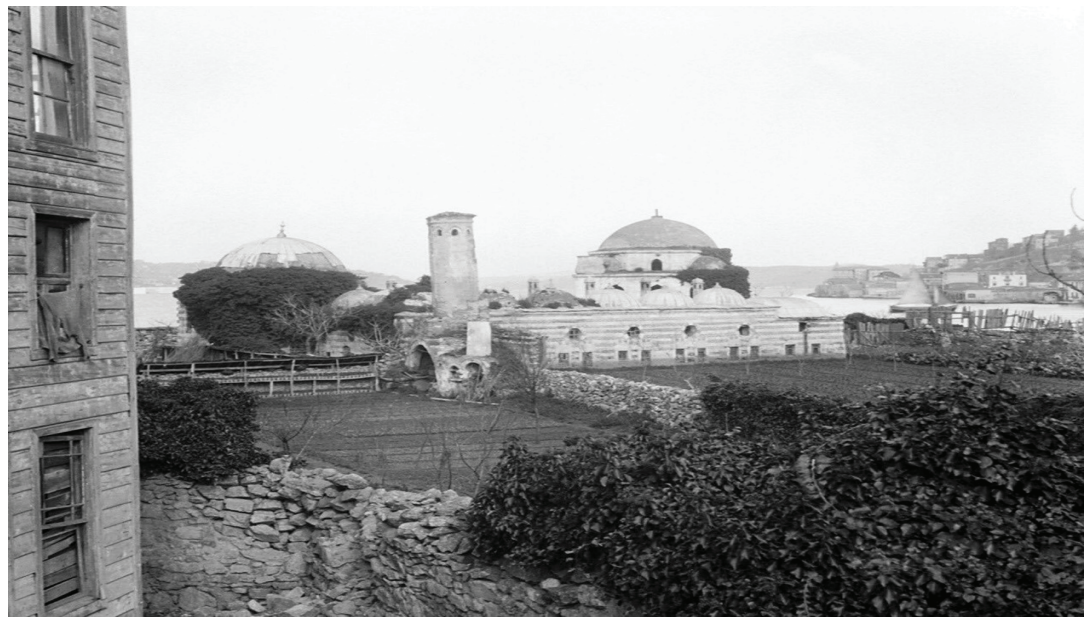

G. 6. Külliyenin harap görüntüsü (www.eskiistanbul.net)

24 Göncüoğlu, "Bir Modernleşme ve Tarihi Yıkımın Hikâyesi; Üsküdar Meydanı," 517-540. 
1986'da yapımına başlanan sahil yoluyla birlikte, 1987 sonbaharında Tekel depolar1 ve Balaban İskelesi'ne ait yapılar yıkılarak, Üsküdar Meydan sınırları Şemsi Ahmed Paşa Külliyesi'ne kadar dayanmıştır. ${ }^{25}$ Aynı zamanda bu sahil yoluyla birlikte Şemsi Paşa Meydanı'nın bir kısmı da bu yola kurban gitmiştir. Bugün meydandan artakalan kısımlarda ticari mekânlar bulunmaktadır ve Şemsi Paşa Meydanı'ndan eser kalmamıştır. Kıyı boyunca kazıklarla destekli sahil yolu yoğun bir trafiği buraya taşımış ve kıyıla kurulan ilişkiye zarar vermiştir.

Son yıllarda İstanbul Büyükşehir Belediyesi tarafından hazırlanan ve 2017 yılı itibariyle uygulamaya sokulan ve bugün bir kısmı faaliyette olan "Üsküdar Meydanı Düzenleme" projesi kapsamında "Tarihi yapıları ortaya çıkarıyoruz." ifadeleriyle birlikte meydan boşaltılmıştır. Hâlbuki tarihi yapılar, etrafında var olanla birlikte kamusal bellekte yer edinmiş̧ir. Ayrıca projeye göre kıyı hattı boyunca planlanan kazıklı yürüyüş yoluyla birlikte Şemsi Ahmed Paşa Külliyesi'nin kıyısı da doldurulmak istenmiştir. $\mathrm{Bu}$ girişim, yapının kıyı külliyesi olma özelliğini bir nevi ihlal etme olarak tanımlanabilir. 2017 yılında, halk tarafından gelen tepkiler üzerine sadece külliye önündeki kazıklı yoldan vazgeçildiğine ve cami önüne denk gelen (G. 7), kısmen çakılmış olan kazıkların kesilmek suretiyle dolgu yapılmayacağına dair dönemin belediye başkanı tarafından beyanat verilmişti. ${ }^{26}$ Lakin bu beyanata aykırı davranıldığı ve var olan kazıkların üzeri betonla kaplandığı görülmektedir (G. 8).

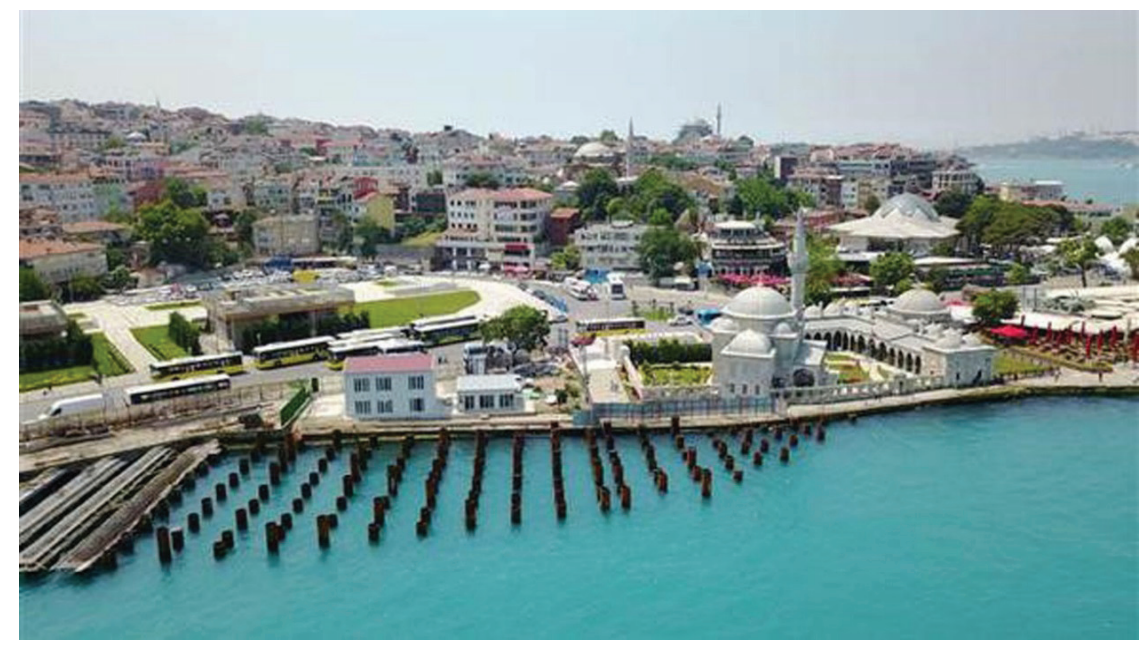

G. 7. Üsküdar Meydanı Düzenleme Projesi kapsamında denize çakılan kazıklar (www.hurriyet.com.tr)

25 İmre Özbek, "Üsküdar Meydanı’nın Toplumsal Veriler Doğrultusunda Geçirdiği Mekânsal Dönüşüm,” 2. Üsküdar Seтроzуити, (İstanbul: Üsküdar Belediyesi, 2005), 2: 371-383.

26 “Topbaş: Şemsi Paşa Camii'nin İçerisinde Çatlak Yok,” Hürriyet, 23 Haziran 2017, erişim 1 Ocak 2018, http://www.hurriyet.com.tr/topbas-semsi-pasa-camiinin-icerisinde-catlak-yok-40499292 


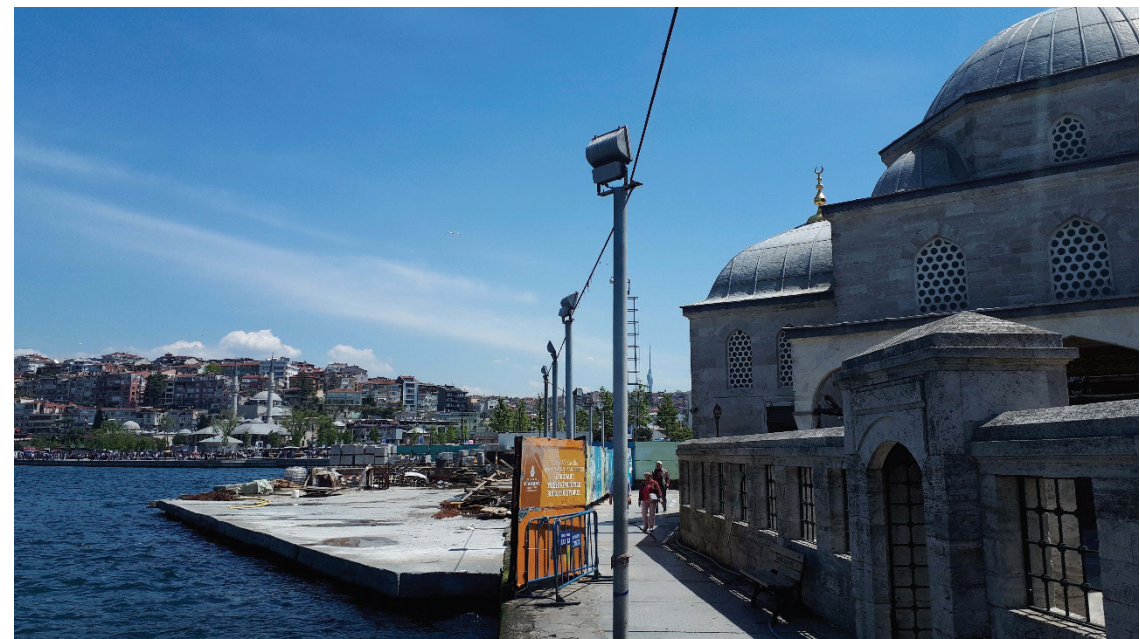

G. 8. Yeni dolgu alanı ile külliyenin ilişkisi (Safa Meral, 2019)

\section{Günümüze Kadar Geçirdiği Onarımlar}

“Evkâf Defterleri’ndeki kayıtlara göre, 1871 yılında Üsküdar Şemsi Paşa Camii’nin tamiri Yamandi adında bir kişi tarafından yapılmıştır. Bir başka Evkâf Defteri'nde yapının 1885 yılında da tadilat geçirdiği görülmektedir. 1892 yılında Üsküdar Şemsi Ahmed Paşa Camii, medrese ve türbesinin tümünün 35.446 kuruşla tamiratının yapılacağ1 kaydedilmiştir.' ${ }^{27}$ Yine cami, 1894 zelzelesinden çok zarar görmüş ${ }^{28}$ ve tamire ihtiyaç duyulmuştur. Külliyenin deniz kenarındaki konumundan ötürü rutubetin fazlalığgı, rıhtımın çökme eğilimi ve altyapıda lağımların bozulmuş olmasından dolayı 1914 yılında onarımın gerekliliği ifade edilmiş lakin şartların elverişli olmadığı belirtilmiştir. $^{29}$

$\mathrm{Bu}$ tarihten sonra yapının tamiriyle ilgili herhangi bir bilgiye rastlanılmamaktadır. Meşrutiyetten sonra sütunların yağmalandığı ifade edilmiştir. ${ }^{30}$ Balkan savaşları sırasında ve 1914 yılında ise medrese içerisinde göçmenler barınmıştır. ${ }^{31}$ Külliyenin harabe hâlindeki durumu 1938 yılına kadar devam etmiştir. Cumhuriyet'in ilk yıllarında en belirleyici devlet politikası olan ulus devlet oluşturma ideali çerçevesinde şekillenen politik yaklaşımın uzantısı olarak Osmanlı'nın 18. yüzyılına kadar uzanan tarihi yapılarının ulus ruhunu yansıttığı kabul edilmiştir. ${ }^{32} \mathrm{Bu}$ yapılar, bir mimarlık

27 Şenyurt, “Şemsi Ahmed Paşa’nın Üsküdar'daki Yapıları Üzerine Bir Değerlendirme,” 176.

28 Ebru Karakaya, "Şemsi Paşa Külliyesi," Türkiye Diyanet Vakfi İslam Ansiklopedisi, c. 38 (İstanbul: Türkiye Diyanet Vakfi, 2010), 529-530.

29 Şenyurt, "Şemsi Ahmed Paşa'nın Üsküdar'daki Yapıları Üzerine Bir Değerlendirme," 177.

30 Yücel, "Şemsi Paşa Külliyesi," 159.

31 Karakaya, "Şemsi Paşa Külliyesi," 529-530.

32 Mehmet Șener, "Reviewing The Periodical Yapı (1941-1943): A Study On Architectural Practice And Ideology In Turkey During The Second World War" (Yüksek Lisans Tezi, Orta Doğu Teknik Üniversitesi, 2006), 112. 
mirası kabul edilerek koruma anlayışı ortaya çıkmış ve bu yaklaşımdan Şemsi Ahmed Paşa Külliyesi de payına düşeni almıştır. Bu sebeple külliyenin Türk ulusunun tarihini ve ruhunu simgeleyen bir yapı kategorisinde ele alınması, benzer diğer yapılarla birlikte bu külliyenin de 1938'de korunmasını ve restore edilmesini sağlamış olabilir.

İbrahim Hakkı Konyalı, yazdığı çeşitli yazılarla duruma dikkat çekmeye çalışır. Abideleri ve Kitabeleriyle Üsküdar Tarihi adlı eserinde caminin ihmal edildiğini, minaresinin yıkılmış, kubbesinin çatlamış, üstündeki kurşunlarının soyulmuş, medrese odalarının ve dershanesinin ahır, ağıl, caminin ise abdesthane hâline getirildiğini not düşer. Hatta arsasının satılığa çıkarıldığını 7 Nisan 1938 tarihli Tan gazetesinde yazar." ${ }^{33}$ (G. 9)

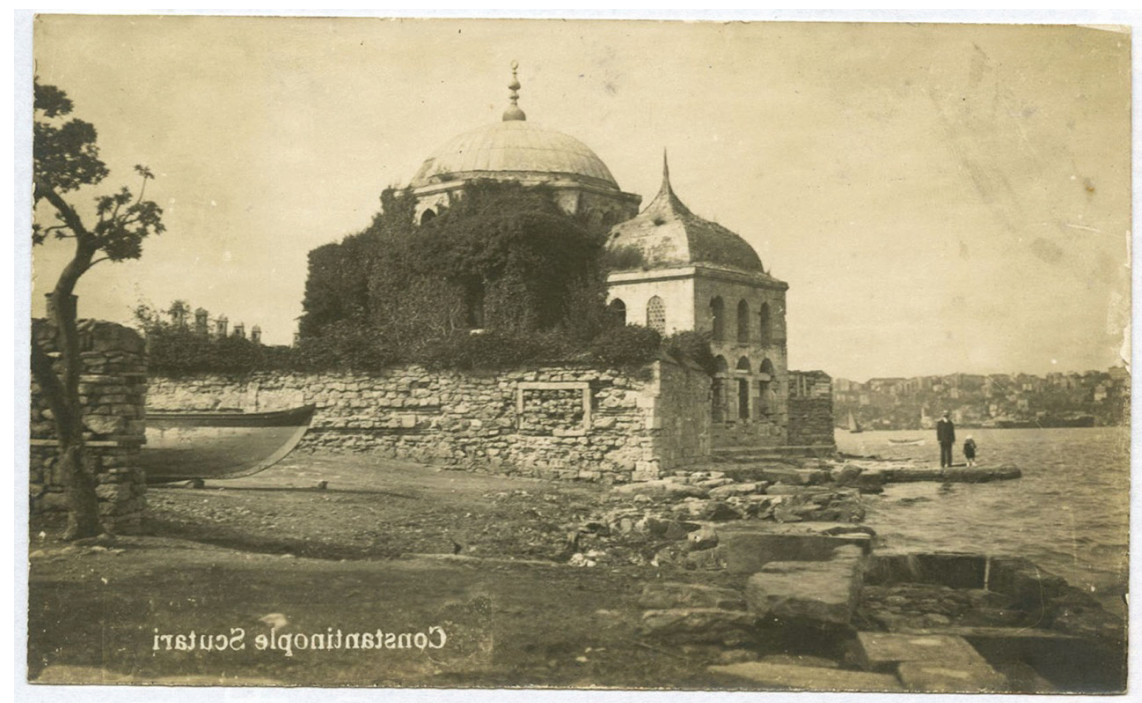

G. 9. Külliyenin 1940 onarımı öncesindeki harap görüntüsü (IBBB Atatürk Kitaplığı)

Bu tespitler, 1938'lerde Osmanlı klasik dönem yapılarına verilen özel önemle birlikte yönetimin dikkatini çekmiştir. Tamiri için 1940 yılında Vakıflar Umum Müdürlüğü tarafından karar alınmış ve yenileme görevi Yüksek Mimar Süreyya Yücel’e verilmiştir ve 1943 yılında ${ }^{34}$ onarımlar (G. 10) tamamlanmıştır. "Çalışmalar sırasında Mimar Sinan'ın minarelerine uygun bir şekilde minare yeniden inşa edilmiş ve ibadet mekânını örten kubbe üzerindeki çatlaklara çıralı çam takozlar çakılmak suretiyle mukavemetleri arttırılmıştır. Ayrıca beden duvarlarının yüzde yetmiş nispetinde taşları değiştirilmiştir." 35 "Camideki pencerelerin renkli camları (vitray) yenidir ve 16'ncı yüzyılın ürünlerini yansıtmaktan çok uzaktır." ${ }^{36}$ Istanbul Abideleri başlıklı kitapta

33 Gülşah Pala, “Üsküdar Şemsi Ahmet Paşa Külliyesi,” Sanatın Yolculuğu, 5 Mart 2017, erişim 1 Ocak 2018, http://www.sanatinyolculugu.com/uskudar-semsi-ahmet-pasa-kulliyesi/

34 Karakaya, "Şemsi Paşa Külliyesi," 529-530.

35 Yücel, "Şemsi Paşa Külliyesi,” 160.

36 Suut Kemal Yetkin, “Şemsi Paşa Külliyesi,” Sanat Dünyamız 19 (1980): 6. 
meşrutiyet devirlerinde yağma edilen sütunlardan bazılarının onarımına başlanırken Üsküdar İskele Meydanı'nda ve dönemin itfaiye binasında birer adet bulunduğu ve bunların müezzin mahfiline ait olduğunun anlaşıldığı yazmaktadır. ${ }^{37}$ Ayrıca türbeyi örten ayna tonozun alemi (G. 9) değiştirilerek bugünkü hâline getirilmiştir (G. 8). Bu onarımla birlikte medresenin revakları camekânla kapatılarak 1953 yılında yap1, Üsküdar Halk Kütüphanesi’ne dönüştürülmüştür. ${ }^{38} 1958$ yılında yapının tamiri ihaleye çıkarılmış ve eksiltme usulüyle tamirine karar verilmiştir. ${ }^{39}$

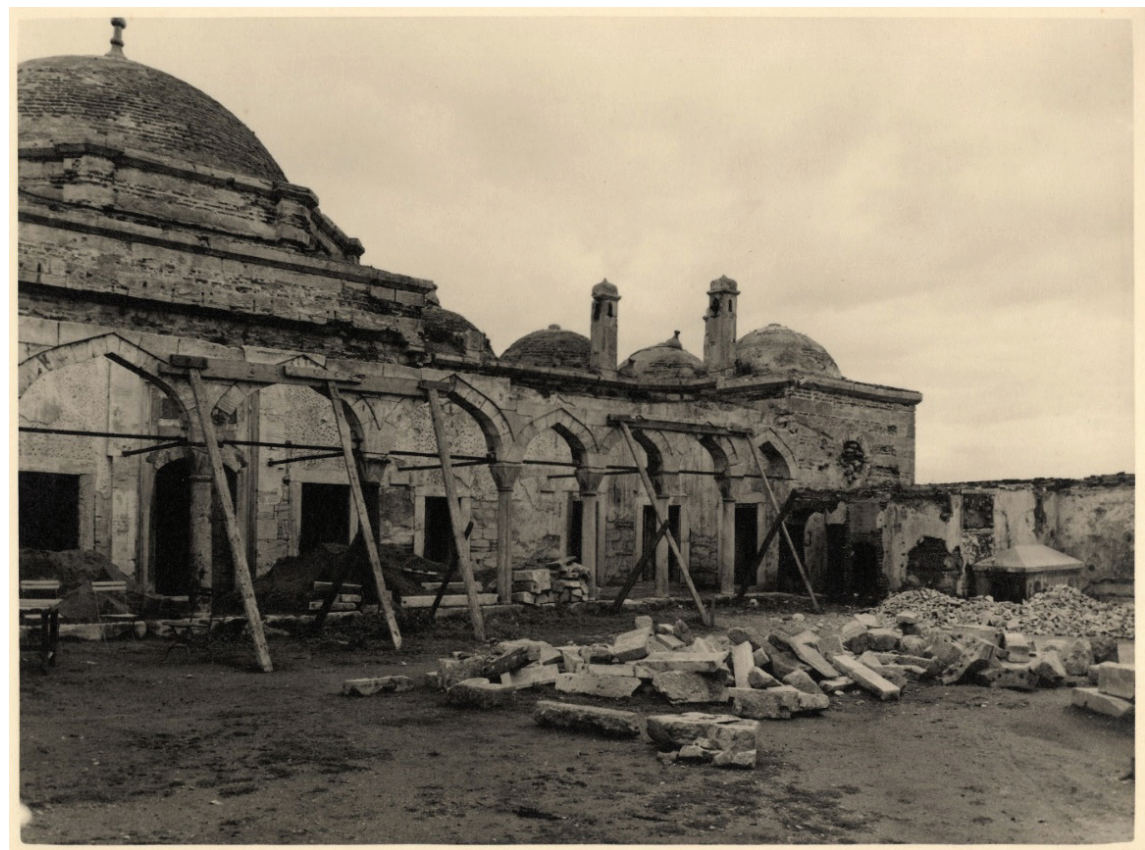

G. 10. 1940 onarımı sırasında medrese (Ali Saim Ülgen Arşivi, 1944)

2008-2010 yıllarında cami ve türbe için gerçekleştirilen son onarımda deniz yönüne tehlikeli bir eğim gösteren minare aslına uygun biçimde tamir edilmiştir. Genel bir onarıma gidilerek taş yüzeylerin onarımı ve konservasyonu, zemin dokusunun, alt yapının düzenlenmesi, kubbe, minare ve saçak örtülerin onarımı, ahşap işleri ve diğer süsleme ve türbe önündeki bronz parmaklığın temizliği dâhil birçok yenileme çalışması yapılmıştır. ${ }^{40} 2015$ yılında külliyeye yeni bir ek dâhil edilmiş, şadırvan ve helalar bu yeni ek içerisinde çözülmüştür. (G. 11) Medresenin restorasyonu 2012 yılının Temmuz ayında İstanbul İl Özel İdaresi tarafından başlatılmıştır. ${ }^{41}$

37 "Şemsi Paşa Camii," 116.

38 Kuran, Mimar Sinan, 194.

39 Şenyurt, “Şemsi Ahmed Paşa’nın Üsküdar'daki Yapıları Üzerine Bir Değerlendirme,” 179.

40 Üsküdar Şemsi Ahmet Paşa Camii Restorasyonu (İstanbul: Yılmaz Yap1, 2010), 16-74.

41 “Şemsi Paşa Halk Kütüphanesi Restore Ediliyor,” Habertürk, 31 Ekim 2012, erişim 19 Mayıs 2019, https:// www.haberturk.com/kultur-sanat/haber/789950-semsi-pasa-halk-kutuphanesi-restore-ediliyor 


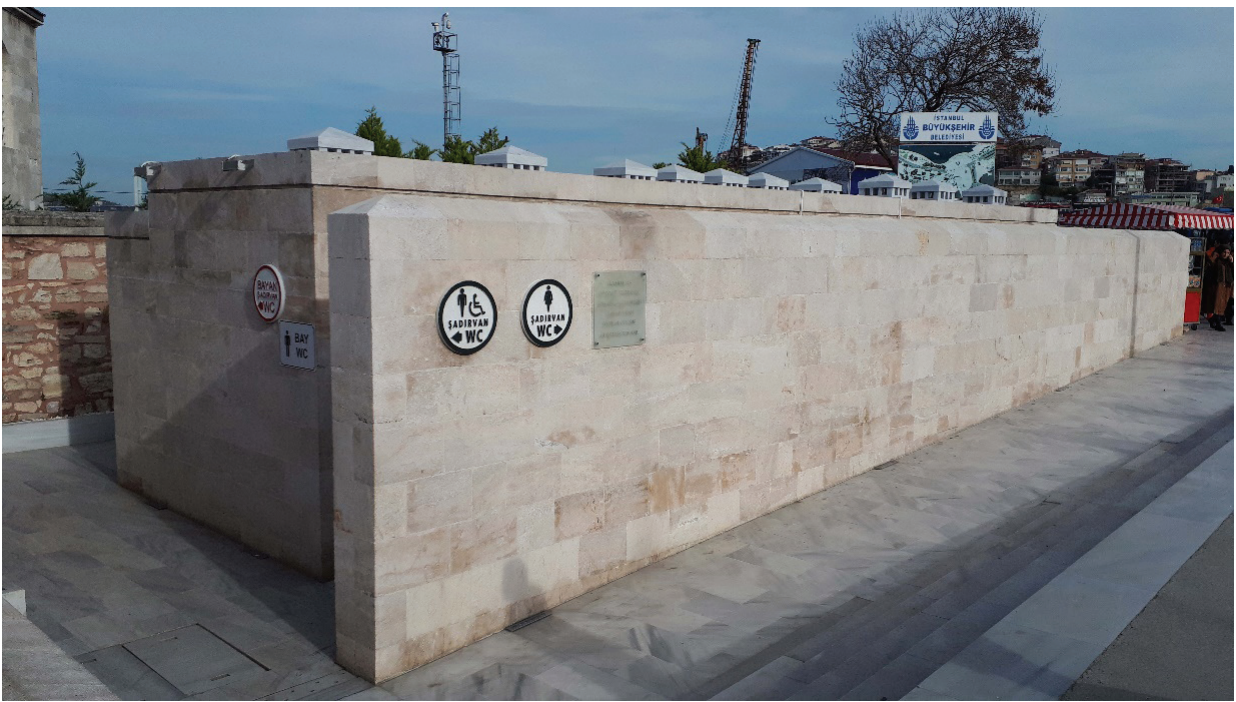

G. 11. 2015 y1lında külliyeye dâhil edilen yeni ek yapı (Safa Meral, 2017)

\section{Restorasyon Sonrası Güncel Durum}

Yapının yıkılma tehditlerine rağmen günümüze kadar ulaşması, mimari mirasın gelecek nesillere aktarılması bağlamında önemlidir. Külliye özelinde Cumhuriyet dönemi koruma yaklaşımlarının okunduğu yapıda mevcut sorunların tespiti ve bunları gözlemlenmesi yapının sürekliliği açısından önemlidir. Bu bağlamda, yapı kabuğundaki mevcut ve oluşabilecek bozulmaların kızılötesi termal kamera çekimleri yapılarak belirlenmesi hedeflenmiştir. Ayrıca, ICOMOS Türkiye Mimari Mirası Koruma Bildirgesi'nde ${ }^{42}$ belirtildiği üzere koruma eylemi, kültür varlığının sürdürülebilirliğini sağlamak üzere, malzemeleri sağlamlaştırarak var olanı koruma diye tanımlanmıştır. Bu tanım doğrultusunda, restorasyon faaliyetinin sürdürülebilir olması ve kapsamlı restorasyon sonrasında olası bir bozulmanın gerçekleşmemesi beklenmektedir. $\mathrm{Bu}$ bağlamda, uzun yıllar boyunca müdahale görerek günümüze ulaşmış Şemsi Ahmed Paşa Külliyesi yapılarının, son onarımdan sonra yapısal ya da nem kaynaklı probleme sahip olup olmadığı araştırılmıştır.

Son restorasyon çalışmaları yakın tarihte yapıldığı için yapıda strüktürel hasarlar pek görülememiştir. Yapısal çatlakların görüldüğü noktalar külliyenin bahçe duvarlarındadır. "Üsküdar Meydanı Düzenleme Projesi”" kapsamında kazık çakma işlemlerinin bahçe duvarlarında çatlaklara sebep olduğu iddia edilmektedir (G. 12). Ayrıca, dışarıdan gözlem yoluyla yapılan incelemelerde cami ve medresede yer yer sıvalarda çatlamalar ve nemden kaynaklı bozulmalar görülmektedir. Bu bölgelerde kızılötesi termal kamerayla çekimler gerçekleştirilmiştir. Öngörülen nedenlerin doğruluğu için

42 “Mimari Mirası Koruma Bildirgesi,” ICOMOS Türkiye, erişim 30 Aralık 2019 http://www.icomos.org.tr/Dosyalar/ICOMOSTR_tr0784192001542192602.pdf 
yüzey sıcaklıklarıyla karşılaştırma yapılmıştır. Bunun nedeni, 19. yüzyıldan itibaren onarım faaliyetlerinin irdelendiği bu çalışmada, son restorasyon çalışmalarının ardından yapıların güncel koruma sorunlarını bozulmalar özelinde incelemektir.
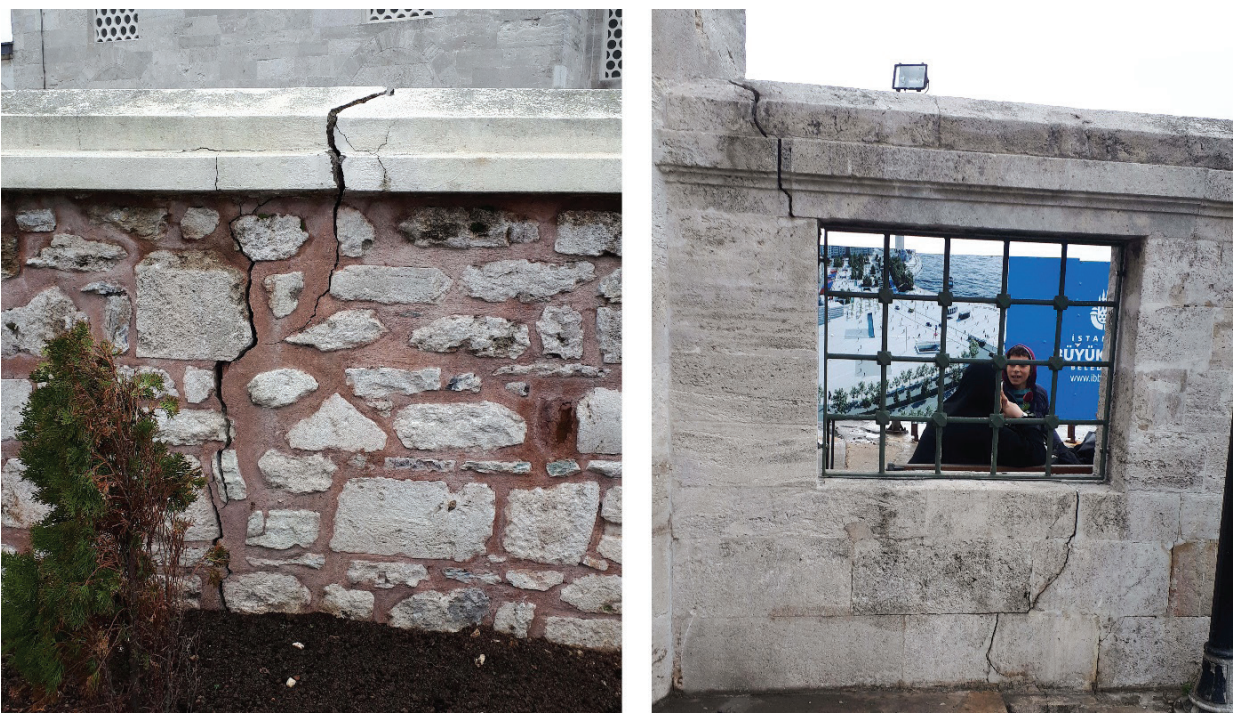

G. 12. Bahçe duvarlarında tespit edilen çatlaklar (Safa Meral, 2017)

Termografiyle yapı yüzeylerinden 1şıma yoluyla yayılan kızılötesi dalgaların dağılımı ve miktarı görüntülenebilmektedir. Duvar ve çatı yüzeylerindeki sıcaklık dağılımı ve 1sı kayıpları farklı malzeme, boşluk, bozulma ve çatlakların bulunduğu kısımlarda farklılaşmaktadır. Buna bağlı olarak, bu yöntem yapı elemanlarındaki 1sı transferleriyle çatlakları gözlemlemek mümkündür. Ayrıca, yapı kabuğunun iç ve dış kısımlarında nem kaynaklı bozulmaları belirlemek için Kızılötesi Termal Kamera görüntüleme yöntemleriyle detaylı incelemeler gerçekleştirilmiştir. Bu yolla, nem/su kaynaklı bozulmalar, yapıya dair gözle görünmeyen çeşitli detaylar ve maruz kaldığı müdahaleler, 2019 yılı Mayıs ayında yapılan çekimlerle ortaya çıkarılmıştır. Caminin kuzeybatı iç yüzeyinde yapılan termografi çalışmasıyla birlikte yüzeyde daha soğuk alanlar tespit edilmiştir. Nemden kaynaklanan bu alanın, cami minaresinin yarım kubbeyle birleştiği bölgede olması, yağmur gibi dış etkenlerden kaynaklanan suyun iç yüzeyde bulunması olarak açıklanabilir (G. 14). Ayrıca, kuzeydoğu cephesine bakan beden duvarının iç yüzeyine termal kamerayla bakıldığında, türbenin tonoz örtüsüyle cami beden duvarının birleştiği alanda yine soğuk yüzeyler tespit edilmiştir (G. 15). Türbenin beden duvarlarının iç yüzeyi incelendiğinde çimento bazlı sıvayla müdahaleler dikkat çekmektedir. Yine türbede iki pencere arasında bir çatlak ve çeşitli yerlerde tuzlanmalar gözlemlenmiştir (G. 13). 


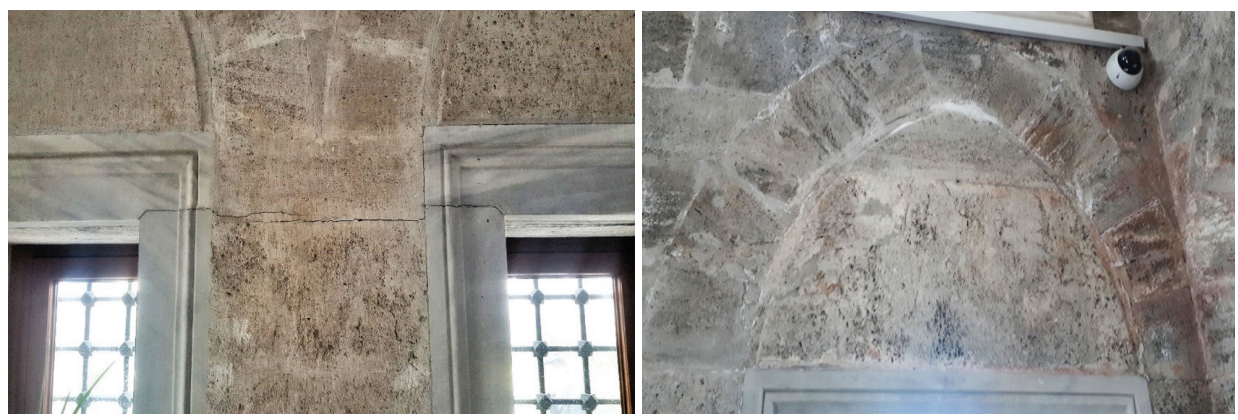

G. 13. Türbede iki pencere arasındaki çatlak (sol) (Emre Kishalı, 2019) ve Türbede pencere üzerindeki tuzlanmalar (să̆) (Safa Meral, 2019)
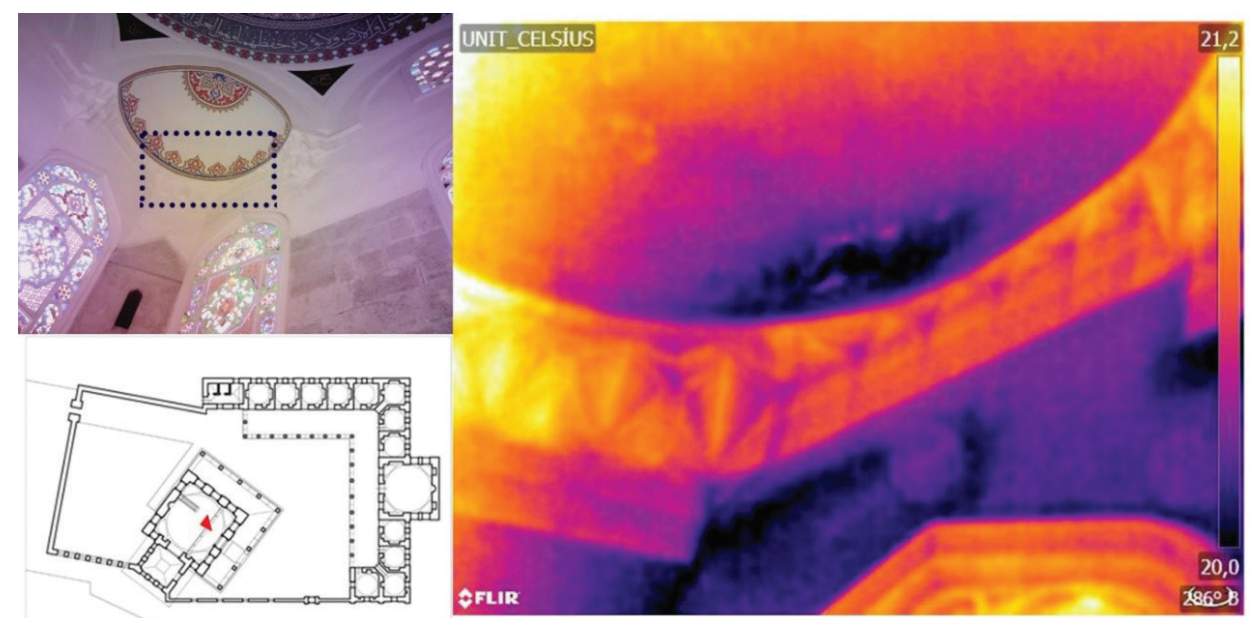

G. 14. Cami kuzeybatı yarım kubbe iç duvar yüzey sıcaklık dağılımı (Emre Kishalı, 2019)
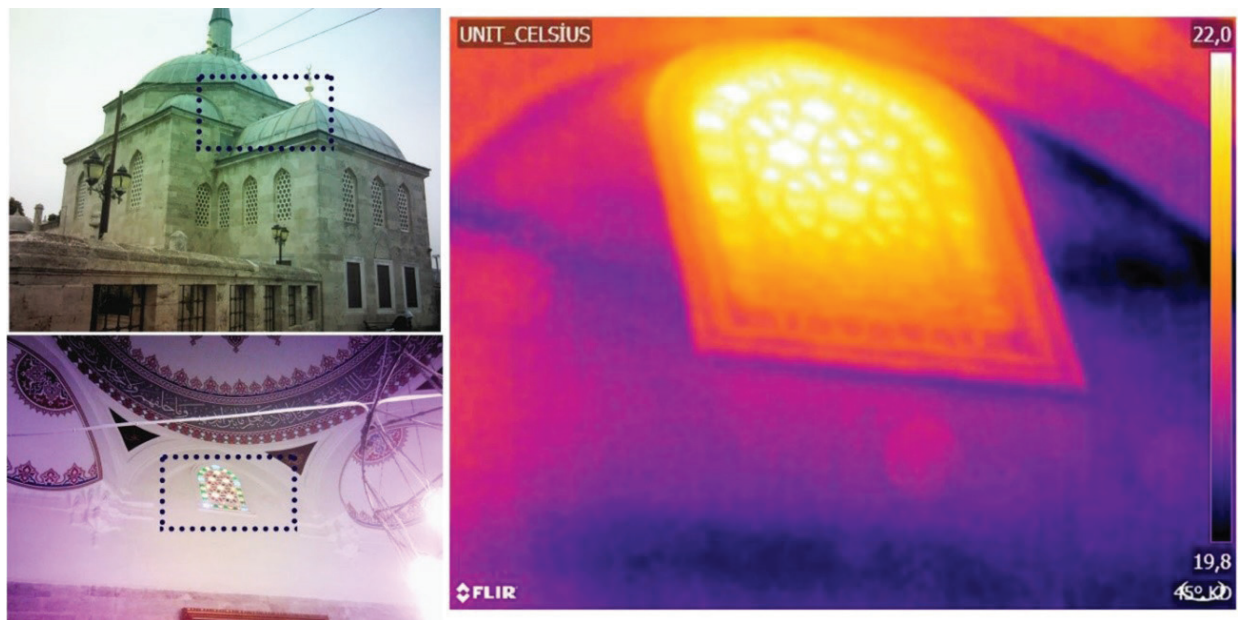

G. 15. Cami kuzeydoğu iç duvar yüzey sıcaklık dağılımı (Emre Kishalı, 2019) 
Caminin güneydoğu cephesi incelendiğinde taşların yüzey sıcaklıklarında farklar olduğu görülmüştür. Ayrıca, pencere açıklıkları ve alçı şebekeleri çevresinin iç ve dış yüzey sıcaklıkları, beden duvarlarıyla karşılaştırıldığında elde edilen değerlerin daha yüksek olduğu görülmektedir. Yüzey sıcaklıklarının 2 - 4 derece kadar fark etmesi, taşların özellikleriyle ilişkili olduğuna işaret edebilmektedir. Bu durum ilave hasarlı ve hasarsız testlerle araştırılmalıdır. Öte yandan, 4 Mayıs tarihinde yapılan çalışmada dış ortam sıcaklık değeri yaklaşık 22.5 derece olarak ölçülmüştür. Bu bölgelerden, içeriden dişarıya sıcak hava kaçışının olması mümkün gözükmemektedir. Cami güneybatı cephesi ve medrese beden duvarlarında yapılan termal kamera çekimlerinde, cami güneydoğu cephesinde görülen farkların bulunmaması bu durumu güçlendirmektedir. Dolayısıyla, incelenen alanda yapı malzemelerinin farklı fiziksel ve kimyasal özellikler göstermesi muhtemeldir (G. 16).

Yüzeyde sıva dökülmeleri ve renk değişikliğine kütüphane olarak kullanılan medrese yapısının kuzey iç yüzeyinde de rastlanmıştır (G. 17). Bozulmanın gerçekleştiği alanın üstünde bulunan pencere açıklığından gelen suyun bu duruma neden olduğu düşünülmektedir. Ayrıca, son restorasyonda uygulanan pencere detayı çözümünün bozulmaya yol açtığı tahmin edilmektedir.

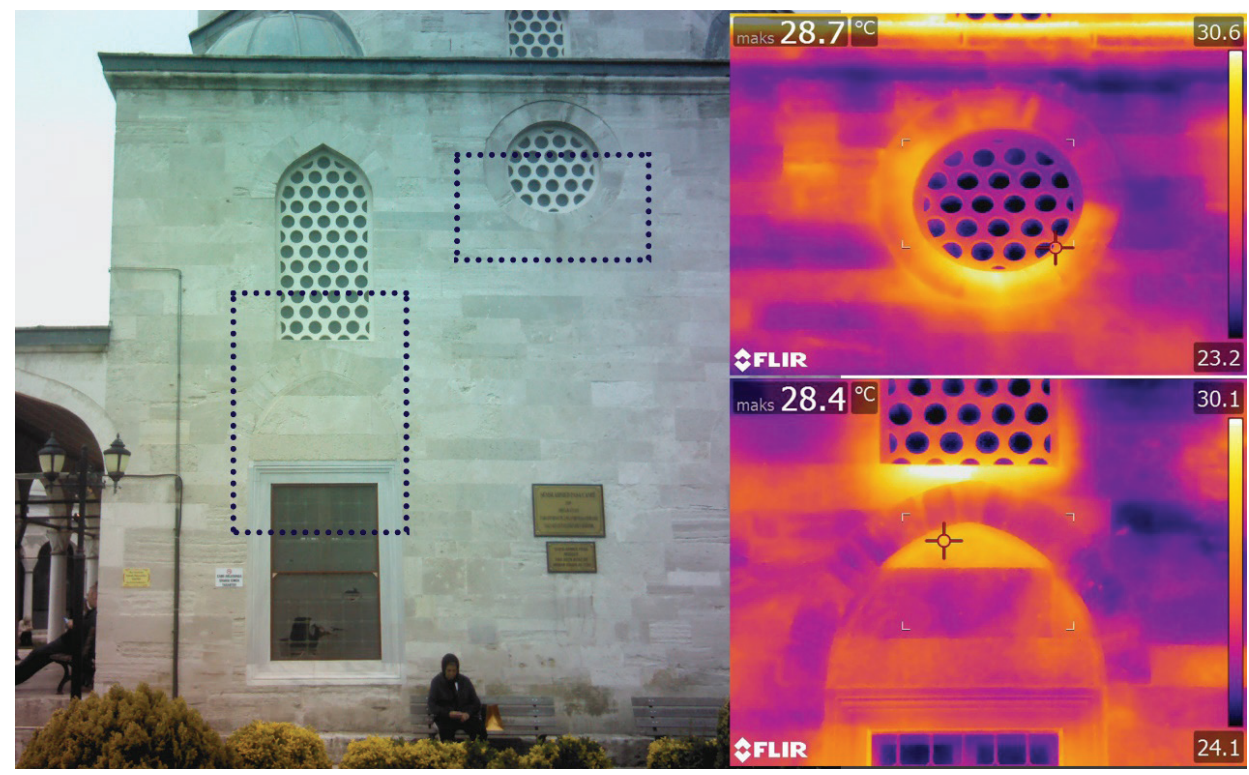

G. 16. Cami güneydoğu cephesi yüzey sıcaklık dağılımı (Emre Kishalı, 2019) 

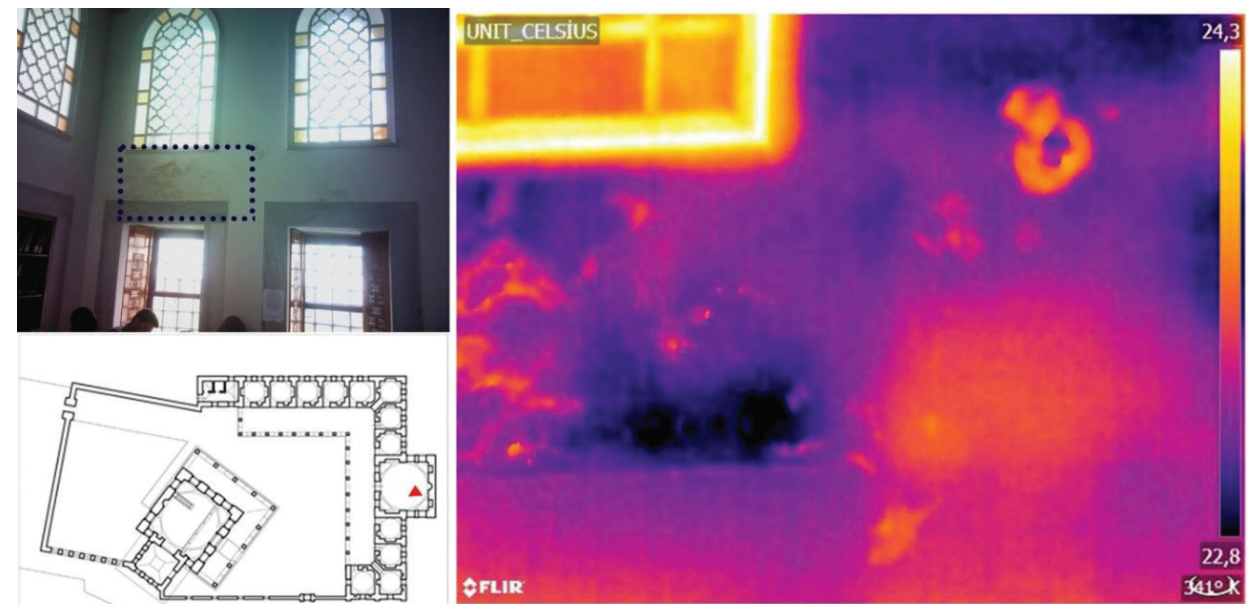

G. 17. Medrese kuzey iç duvar yüzey sıcaklık dağılımı (Emre Kishalı, 2019)

Kütüphane olarak işlev gören medresede yoğun bir kullanım gözlenmiştir. Bu yoğun kullanım, medresenin mikro iklimsel durumunu etkilemektedir. Bu durum dershane odasının iç yüzeylerinde sıva dökülmelerine sebebiyet vermiştir. Bu duruma sebep olarak bağıl nemin artışını gösterebiliriz. Revaklardaki sabit camekânların bu artışa neden olduğu düşünülmektedir. Bu müdahale yapının doğal havalandırmasına engel olacak şekilde kurgulanmıştır. Tarihi yapılar için öngörülen bağı nem oranının \%30-60 arasında ve küf oluşumu için bağıl nem koşullarının çeşitli kaynaklarda \%70-85 arasında olduğu belirtilmiştir. ${ }^{43} \mathrm{Bu}$ yüzden detaylı mikro iklimsel araştırmayla gözlem altında tutulmalıdır.

\section{Sonuç}

Şemsi Ahmed Paşa Külliyesi, asimetrik biçimde planlanması, külliye içerisindeki yapıların birbirleriyle kurdukları ilişkiler ve bunlarla birlikte ölçek olarak da küçük olması onu diğer Sinan yapılarından farklılaştırmış ve ayrıcalıklı bir konuma yükseltmiştir. Ayrıca bu yapı Sinan'ın sürekli bir arayış içerisinde olduğunun ve bu bağlamda herhangi bir zihnî tabusunun olmadığının da önemli bir göstergesidir. Ayrıca tarihsel bağlam içerisinde Şemsi Ahmed Paşa'nın Üsküdar için önemi, külliye üzerinden Üsküdar siluetine yaptığı katkıyla kendini göstermektedir.

Tarih boyunca yapılan onarımlar ve bu süreçlerde yapılan bazı değişimlerle birlikte külliye günümüze şu anki hâliyle ulaşmıştır. Özellikle bu onarımlar içerisinde külliyenin 1940 yılında geçirdiği restorasyon çalışması, harabe hâlde bulunan külliyenin

43 Emre Kishalı, Neslihan Türkmenoğlu Bayraktar ve Mehmet Şener, "Kocaeli Tarihi Cami Örnekleri Üzerinden Planlı Koruma Kapsamında Hasarsız Test Uygulamaları: Çoban Mustafa Paşa Camii, Fevziye Camii ve Pertev Paşa Camii," Metu Journal of the Faculty of Architecture Advance Online 36 (Mayıs, 2018): 9, erişim 3 Haziran 2019, https://doi.org/10.4305/METU.JFA.2018.2.6 
günümüze ulaşmasında hayati bir müdahaledir. Ayrıca Balkan savaşları sırasında ve 1914'te medrese eğitim faaliyetlerinden uzaklaşmış ve içerisinde göçmenler barınmıştır. Bu bağlamda değerlendirildiğinde 1953 yılında eğitimden uzak kalmış medresenin kütüphaneye çevrilerek tekrardan eğitim faaliyetlerini nitelik olarak farklı da olsa sürdürüyor olması işlevin mekânsal sürdürülebilirliği açısından olumlu değerlendirilebilir. Lakin kapasitesinin üzerindeki yoğun kullanım nemden kaynaklı bozulmalara sebebiyet vermektedir.

Şemsi Ahmed Paşa Külliyesi için esas bozulma kentsel bağlam içerisinde gerçekleşmiştir. Son 150 yıllık süreç içerisinde yapı grubunun kentsel bağlamı sürekli bir değişim hâlindedir. 1869 yılında külliyenin batısında yer alan Şerefâbâd Kasrı'nın yıktırılması, 1980'lerde sahil yolunun açılması, külliyenin doğusunda yer alan Tekel depoları ve Balaban İskelesi'ne ait yapıların yıkılmasıyla oluşan Üsküdar meydanının sınırları külliyeye kadar dayanmıştır. Son olarak günümüzde yeni dolgu alanıyla birlikte niteliksiz büyük bir boşluğun içerisinde meydanın ticari mekânlarla sarmalanmış olması, kıyıyla ilişkisinin ciddi tehlike altına girmesi, kentsel bağlamın nasıl değiştiğini adım adım gösterir. Bu minvalde külliyenin gelecek nesillere tarihsel çevresi ile birlikte sağlıklı bir şekilde aktarılamaması yanlış şehirleşme politikalarından kaynaklanmaktadır.

Son restorasyon çalışmalarından sonra yaptı̆̆ımız incelemeler sonucunda, külliye yapılarında ciddi yapısal hasarlara rastlanmamış, haricen bahçe duvarlarında strüktürel çatlakların varlığı gözlenmiş̧ir. Bahçe duvarlarındaki bu çatlaklara yakın çevrede gerçekleştirilen dolgu alanı çalışmalarının sebep olduğu iddia edilmektedir. Ayrıca yapı grubunun geçirmiş olduğu müdahaleler hem dışarıdan gözlem hem termografi yöntemiyle incelendiğinde, yapılarda nemden kaynaklanan sorunların olduğu tespit edilmiştir.

Yakın zamanda restorasyonu gerçekleşmiş olan tarihi yapılarda, nemden kaynaklı bozulma problemlerine rastlanması, sürdürülebilir koruma ilkelerine uygun olarak restorasyon uygulamaları yapılması gerekliliğini tekrar ortaya çıkarmaktadır. Ayrıca koruma anlayışının salt, tek başına tarihi yapı özelinde değil onunla birlikte var olan, onu var eden tarihsel bağlamı göz ardı etmeden kentsel belleğin diri tutularak geliştirilmesi gerekmektedir. Bu gereklilikler kendini Şemsi Ahmed Paşa Külliyesi özelinde bir kez daha göstermektedir.

Hakem Değerlendirmesi: Dış bağımsız.

Çıkar Çatışması: Yazarlar çıkar çatışması bildirmemiştir.

Finansal Destek: Yazarlar bu çalışma için finansal destek almadığını beyan etmiştir.

Peer-review: Externally peer-reviewed.

Conflict of Interest: The authors have no conflict of interest to declare.

Grant Support: The authors declared that this study has received no financial support. 


\section{Kaynakça/References}

Ali Saim Ülgen Arşivi, Üsküdar Şemsi Paşa Camii Fotoğraf ve Rölöve krokileri. SALT Araştırmalar Merkezi, 13 Temmuz 1944. Erişim 23 Kasım 2017. https://archives.saltresearch.org/handle/123456789/73527

Cansever, Turgut. Mimar Sinan. İstanbul: Albaraka Türk Yayınları, 2005.

Eldem, S. Hakkı. Köşkler ve Kasırlar = A Survey of Turkish Kiosks and Pavilion. 2 cilt. İstanbul: Devlet Güzel Sanatlar Akademisi, 1974.

“Eski İstanbul: Şemsipaşa Camii/Üsküdar.” Erişim 3 Haziran 2019

http://www.eskiistanbul.net/1088/eski-istanbul-semsipasa-camii-uskudar

Göncüoğlu, Süleyman Faruk. "Bir Modernleşme ve Tarihi Yıkımın Hikâyesi; Üsküdar Meydanı." 6. Üsküdar Sempozyumu, 2 cilt. İstanbul: Üsküdar Belediyesi, 2008. 517-540.

Haskan, Mehmet Mermi. Yüzyıllar Boyunca Üsküdar. 3 cilt. İstanbul: Üsküdar Belediyesi, 2001.

İnciciyan, P. Ğugios. XVIII. Asırda İstanbul. Çev. Hrand D. Andreasyan. İstanbul: İstanbul Fetih Cemiyeti İstanbul Enstitüsü, 1976.

İstanbul Şehir Haritası. Erişim 3 Aralık 2017, https://sehirharitasi.ibb.gov.tr/

Karakaya, Ebru. "Şemsi Paşa Külliyesi." Türkiye Diyanet Vakfi İslam Ansiklopedisi. 38. İstanbul: Türkiye Diyanet Vakfi, 2010. 529-530.

Kishali, Emre, Neslihan Türkmenoğlu Bayraktar ve Mehmet Şener. "Kocaeli Tarihi Cami Örnekleri Üzerinden Planlı Koruma Kapsamında Hasarsız Test Uygulamaları: Çoban Mustafa Paşa Camii, Fevziye Camii ve Pertev Paşa Camii." METU Journal of the Faculty of Architecture Advance Online 36 (Mayıs, 2018): 1-30. Erişim 3 Haziran 2019. https://doi.org/10.4305/METU.JFA.2018.2.6

Kuran, Aptullah. Mimar Sinan. İstanbul: Hürriyet Vakfi, 1986.

“Mimari Mirası Koruma Bildirgesi.” ICOMOS Türkiye. Erişim 30 Aralık 2019. http://www.icomos. org.tr/Dosyalar/ICOMOSTR_tr0784192001542192602.pdf

Necipoğlu, Gülru. Sinan Çă̆l: Osmanlı İmparatorluğu'nda Mimari Kültür. İstanbul: İstanbul Bilgi Üniversitesi Yayınları, 2013.

Özbek, İmre. “Üsküdar Meydanı'nın Toplumsal Veriler Doğrultusunda Geçirdiği Mekânsal Dönüşüm.” 2. Üsküdar Sempozyumu. 2 cilt. İstanbul: Üsküdar Belediyesi, 2004. 371-383.

Pala, Gülşah. “Üsküdar Şemsi Ahmet Paşa Külliyesi.” Sanatın Yolculuğu. 5 Mart 2017. Erişim 1 Ocak 2018. http://www.sanatinyolculugu.com/uskudar-semsi-ahmet-pasa-kulliyesi/

Şener, Mehmet. "Reviewing The Periodical Yap1 (1941-1943): A Study On Architectural Practice And Ideology In Turkey During The Second World War.” Yüksek Lisans Tezi, Orta Doğu Teknik Üniversitesi, 2006.

Şenyurt, Oya. “Şemsi Ahmed Paşa'nın Üsküdar'daki Yapıları Üzerine Bir Değerlendirme.” Kocaeli Üniversitesi Sosyal Bilimler Dergisi, 35 (2018): 163-192.

“Şemsi Paşa Camii.” İstanbul Âbideleri, Yedigün Neşriyat, 116.

“Şemsi Paşa Halk Kütüphanesi Restore Ediliyor.” Habertürk. 31 Ekim 2012. Erişim 19 May1s 2019. https://www.haberturk.com/kultur-sanat/haber/789950-semsi-pasa-halk-kutuphanesirestore-ediliyor

“Topbaş: Şemsi Paşa Camii’nin içerisinde çatlak yok.” Hürriyet. 23 Haziran 2017. Erişim 4 Mayıs 2019. http://www.hurriyet.com.tr/topbas-semsi-pasa-camiinin-icerisinde-catlak-yok-40499292 
Tüfekçioğlu, Abdülhamit. "Üsküdar ve Şam Arasındaki Köprü: Şemsi Ahmed Paşa ve Mimari Eserleri.” 1. Üsküdar Sempozyumu. 2 cilt. İstanbul: Üsküdar Belediyesi, 2003. 9-25.

Üsküdar Şemsi Ahmet Paşa Camii Restorasyonu. İstanbul: Yılmaz Yap1, 2010.

Üsküdar Şemsi Paşa Cami. İBB Atatürk Kitaplı̆̆ı Sayısal Arşiv ve e-Kaynaklar. Krt_005097. Erişim 3 Haziran 2019, http://ataturkkitapligi.ibb.gov.tr/

Yetkin, Suut Kemal. “Şemsi Paşa Külliyesi.” Sanat Dünyamız 19 (1980): 3-9.

Yücel, Erdem. “Şemsi Paşa Külliyesi.” Arkitekt 336 (1969): 157-160. 